
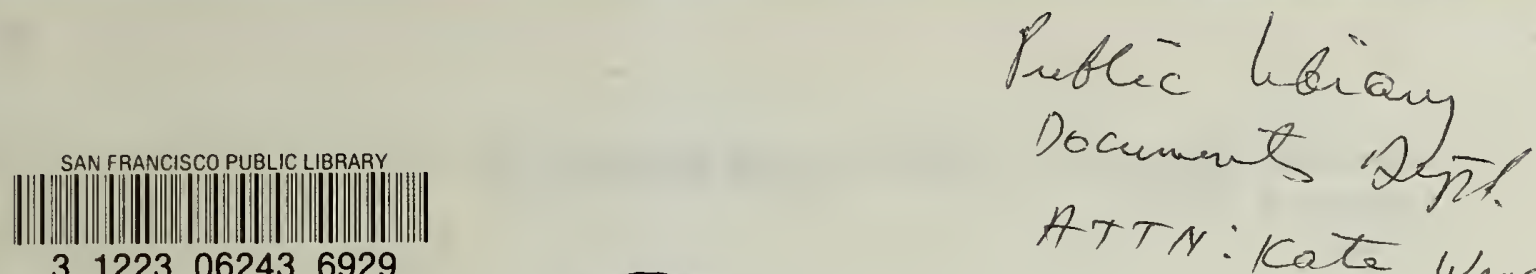

31223062436929

CITY AND COUNTY

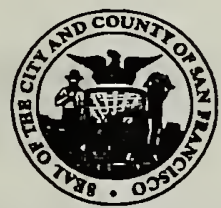

OF SAN FRANCISCO

\title{
BOARD OF SUPERVISORS
}

\section{BUDGET ANALYST}

1390 Market Street, Suite 1025, San Francisco, CA 94102 (415) 554-7642

FAX (415) 252-0461

March 4, 1997

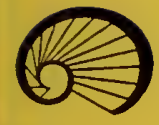

acisco Public Library

nt: :Pormation Center

isco Fublic Library

istragt, 5th Finor

isco, CA 94103

RENCE BOOK

taken from the Library ;or Ammiano

;or Yee

or Leal

ior Katz

Inalyst
DOCUMENTS DEPT.

MAR 051997

SAN FRANCISCO

PUBLIC, LIBRARY

1 Surplus at the San Francisco Zoo

:ed in response to your request to conduct a financial :o Zoo to determine the amount of financial surplus and , from that surplus which may be available to the City's

1993, the City, through the Recreation and Park I Zoo lease and management agreement with the San (SFZS), a non-profit corporation. Under this Zoo lease 1t, the SFZS currently receives an annual $\$ 4$ million ity and the SFZS keeps all admission fees. In turn, the ie ongoing management of the Zoo and operational penses or tne Zoo, which for FY 1996-97 is projected to be approximately $\$ 13.4$ llion. In addition, the City is reimbursed by the SFZS for Civil Service salary and nge benefit expenses for those City personnel performing direct services for the o, utilities and other miscellaneous (yardwork, heavy machinery) services, which e provided by the City. As these Civil Service employees retire, the SFZS will place these employees with SFZS staff. Such reimbursements paid by the SFZS to e City for FY 1996-97 are estimated to total $\$ 4.8$ million The lease and anagement agreement expires on June 30,1998 , but provides for automatic tensions for successive five year periods, up to a total term of 99 years, unless her the City or the SFZS gives written notice of termination by November 30 of e final fiscal year of the then current five-year term.

D Irdance with Section 15.10 of the Zoo lease and management re D e SFZS, at its own expense, must arrange for an annual audit of the ZZS's books and records by an independent, certified public accountant, that is 



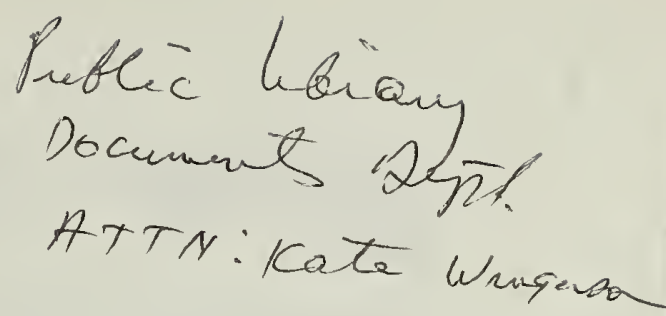

CITY AND COUNTY

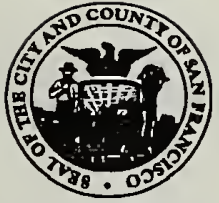

OF SAN FRANCISCO

\section{BOARD OF SUPERVISORS}

\section{BUDGET ANALYST}

1390 Market Street, Suite 1025, San Francisco, CA 94102 (415) 554-7642

FAX (415) 252-0461

March 4, 1997

TO: Supervisor Ammiano

Supervisor Yee

Supervisor Leal

Supervisor Katz

FROM: $\quad$ Budget Analyst

DOCUMENTS DEP'T

MAR 051997

SAN FRANCISCO

PUBLIC LIBRARY

SUBJECT: Financial Surplus at the San Francisco Zoo

This report is prepared in response to your request to conduct a financial analysis of the San Francisco Zoo to determine the amount of financial surplus and the amount of money, if any, from that surplus which may be available to the City's General Fund.

Effective October 9, 1993, the City, through the Recreation and Park Commission, entered into a Zoo lease and management agreement with the San Francisco Zoological Society (SFZS), a non-profit corporation. Under this Zoo lease and management agreement, the SFZS currently receives an annual \$4 million management fee from the City and the SFZS keeps all admission fees. In turn, the SFZS is responsible for the ongoing management of the Zoo and operational expenses of the Zoo, which for FY 1996-97 is projected to be approximately $\$ 13.4$ million. In addition, the City is reimbursed by the SFZS for Civil Service salary and fringe benefit expenses for those City personnel performing direct services for the Zoo, utilities and other miscellaneous (yardwork, heavy machinery) services, which are provided by the City. As these Civil Service employees retire, the SFZS will replace these employees with SFZS staff. Such reimbursements paid by the SFZS to the City for FY 1996-97 are estimated to total $\$ 4.8$ million The lease and management agreement expires on June 30,1998, but provides for automatic extensions for successive five year periods, up to a total term of 99 years, unless either the City or the SFZS gives written notice of termination by November 30 of the final fiscal year of the then current five-year term.

In accordance with Section 15.10 of the Zoo lease and management agreement, the SFZS, at its own expense, must arrange for an annual audit of the SFZS's books and records by an independent, certified public accountant, that is approved by the City's Controller. The Fiscal Year 1995-96 Zoo audit, conducted by 
Memo to Supervisors Ammiano, Yee, Leal and Katz March 4, 1997

Page 2

Pannell Kerr Forster, Certified Public Accountants, was recently submitted to the Recreation and Park Commission for acceptance. The Budget Analyst has reviewed this aucit and found the following:

(1) Total revenues (contributions, membership dues, gate admissions, visitor services, capital funds, interest income, etc.) increased from approximately $\$ 12$ million to $\$ 13$ million, an 8.5 percent increase, from FY 1994-95 to FY 1995-96;

(2) Total expenses (cost of goods and services, animal exhibits and improvements, general administration, capital expenditures, City operations, etc.) declined slightly from approximately $\$ 15$ million to approximately $\$ 14.8$ million, a 1.3 percent reduction, from FY 1994-95 to FY 1995-96;

(3) The annual deficit (total expenses in excess of total revenues) was reduced from approximately $\$ 3$ million to $\$ 1.8$ million, a reduction of 40 percent from FY 1994-95 to FY 1995-96.

(4) As of June 30, 1996 the SFZS had permanently restricted, temporarily restricted and unrestricted assets totalling $\$ 9,378,827$. Of this total, the SFZS had $\$ 2,913,357$ of unrestricted assets and $\$ 937,524$ of permanently restricted assets. These assets are permanently or temporarily restricted by donor-imposed stipulations. The SFZS had an unrestricted assets balance totalling $\$ 5,527,946$, which is less than the SFZS's total liabilities of $\$ 5,556,048$ by $\$ 28,102$. Therefore, as of June 30, 1996, the SFZS had an accumulated deficit of $\$ 28,102$ and, as a result, had no unrestricted available surplus of funds.

As identified above, there was an annual deficit in FY 1995-96 and FY 199495. In addition, the SFZS reports a deficit of approximately $\$ 304,000$ occurred in FY 1993-94. As reflected in the financial statements, the SFZS has been using their unrestricted cash funds to make up the annual revenue shortfalls in the operating deficits incurred by the San Francisco Zoo.

Mr. Wayne Reading, the Chief Financial Officer of the SFZS, reports that the SFZS anticipated that an annual operating deficit would occur the first several years after the SFZS took over the operations and management of the Zoo. According to Mr. Reading, the SFZS Board of Directors approved over $\$ 2$ million of the Zoo's private donation funds to be used to cover these operating deficits for approximately the first four years. Mr. Reading reports that the SFZS has projected that by the end of Fiscal Year 1998-99, the SFZS should be operating on a breakeven basis.

The financial statements for the SFZS reflect that, as of June 30,1996 , there was no financial surplus at the Zoo. Thus, there is no surplus revenues that could be made available to the City's General Fund at this time.

According to Ms. Morley, the language in Section 15.3, SFZS Revenue; Payment of Expenses of the Zoo lease and management agreement currently provides that all revenues received by the SFZS must be expended by the SFZS for 
Memo to Supervisors Ammiano, Yee, Leal and Katz

March 4, 1997

Page 3

Zoo purposes only. Section 15.3 of the lease and management agreement specifically states the following:

SFZS shall collect a minimum of $\$ 7,000,000$ annually in revenue from Zoo operations and contributions to SFZS from other sources (excluding the Management Fee payable hereunder), all of which revenue shall be expended by SFZS on Operating Expenses, capital improvements at the Zoo and other Zoo purposes. All Operating Expenses shall be the obligation of SFZS and shall be paid by SFZS promptly when due. All revenue collected by SFZS at the Zoo, including without limitation fees and receipts from admission, concessions, souvenirs and other services offered by SFZS to the public at the Zoo, and all contributions collected by SFZS from any other source, shall be expended or invested by SFZS exclusively for Zoo purposes.

A review of the SFZS's financial statements indicates that the SFZS collected more than $\$ 7,000,000$ annually in revenue from Zoo operations and contributions, excluding the City's management fee, in both FY 1994-95 and FY 1995-96.

Therefore, Ms. Mariam Morley of the City Attorney's Office reports that under the San Francisco Zoo lease and management agreement, the City may use Zoo revenues for General Fund purposes only if: (1) the SFZS determines that such revenues are not needed by SFZS for any Zoo purposes; or (2) the Zoo lease and management agreement is modified or terminated by the Board of Supervisors.

In summary, the City entered into a Zoo lease and management agreement with the SFZS on October 9, 1993. Since assuming the lease and management responsibilities at the San Francisco Zoo, the SFZS has been operating at an annual deficit. As of June 30,1996, the SFZS had no financial surplus available. According to the City Attorney's Office, any financial surplus of funds, which may become available in the future, could only be made available to the City's General Fund, if: (1) the SFZS determines that such revenues are not needed by SFZS for any Zoo purposes; or (2) the Zoo lease and management agreement is modified or terminated by the Board of Supervisors.

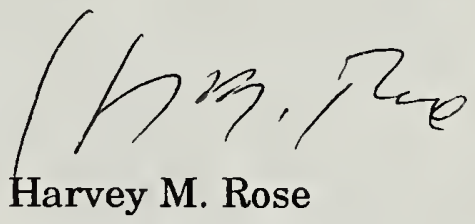

cc: President Kaufman Supervisor Bierman Supervisor Brown Supervisor Medina Supervisor Newsom Supervisor Teng Supervisor Yaki Clerk of the Board Controller

Steve Agostini

Stephen Kawa

Ted Lakey

Controller

David Anderson

Jim Lazarus

Wayne Reading 
$\begin{array}{llll}3 & 1223 & 06243 & 6929\end{array}$ 
